\title{
Topological 3- Rings
}

\author{
K.Suguna Rao ${ }^{1}$, P.Koteswara Rao ${ }^{2}$ \\ ${ }^{I}$ Dept.of mathematics,Acharya Nagrjuna University,Nagarjuna Nagar,Andhara Pradesh,INDIA-522 510. \\ ${ }^{2}$ Dept.of.commerce,Acharya Nagarjuna University,Nagarjuna Nagar,Andhra Pradesh,INDIA- 522510.
}

\begin{abstract}
In this paper we study the 3-rings, Idempotent of 3-ring and some other theorems. In the second section we introduce Ideals on 3-rings, center of 3-rings and theorems, Topological 3-rings and their properties: the set of open neighbourhoods of 0, its properties in topological 3-rings, Every topological 3-ring is a homogeneous algebra and other theorem.
\end{abstract}

Key words: Hausdorff space, Ring, p-ring, Topological space.

\section{Introduction}

D. Van Dantzig firstly introduced the concept of topological ring in his thesis. Later N. Jacobson, L.S. Pontryagin, L.A. Skornjakov Small and S. Warner developed and studied various properties :Connected topological rings, Totally disconnected topological rings, Banach algebras, Ring of P-addict integers, locally compact fields, locally compact division rings and their structure. McCoy and Montgomery introduced the concept of a $p$-ring ( $p$ prime) as a ring $R$ in which $x p=x$ and $p x=0$ for all $x$ in $R$. Thus, Boolean rings are simply 2-rings $(p=2)$., Koteswararao.P in his thesis developed the concept of 3-rings,3-rings generates $\mathrm{A}^{*}$ algebras and their equivalence. With this as motivation, I introduce the concept of Topological 3-rings.

\section{Prelimanaries}

1.1 Definition: A commutative ring $(\mathrm{R},+, .1)$ such that $\mathrm{x}^{3}=\mathrm{x}, 3 \mathrm{x}=0$ for all $\mathrm{x}$ in $\mathrm{R}$ is called a 3-ring.

1.2 Note: $(1) x+x=-x$ for all $x$ in a 3-ring $R$

(2) Here after R-stands for a 3-ring.

1.3 Example: $3=\{0,1,2\}$. Then $(3,+, ., 1)$ is a 3-ring where

\begin{tabular}{|c|c|c|c|}
\hline+ & 0 & 1 & 2 \\
\hline 0 & 0 & 1 & 2 \\
\hline 1 & 1 & 2 & 0 \\
\hline 2 & 2 & 0 & 1 \\
\hline
\end{tabular}

\begin{tabular}{|l|l|l|l|}
\hline$\cdot$ & 0 & 1 & 2 \\
\hline 0 & 0 & 0 & 0 \\
\hline 1 & 0 & 1 & 2 \\
\hline 2 & 0 & 2 & 1 \\
\hline
\end{tabular}

1.4 Example 2: Suppose $X$ is a non empty set .Then $\left(3^{\mathrm{x}},+, .0,1\right)$ is a 3-ring with

(a) $\quad(\mathrm{f}+\mathrm{g})(\mathrm{x})=\mathrm{f}(\mathrm{x})+\mathrm{g}(\mathrm{x})$.

(b) $\quad(\mathrm{f} \cdot \mathrm{g})(\mathrm{x})=\mathrm{f}(\mathrm{x}) \cdot \mathrm{g}(\mathrm{x})$.

(c) $\quad 0(\mathrm{x})=0$.

(d) $\quad 1(\mathrm{x})=1$ for all $\mathrm{x} \in \mathrm{X}, \mathrm{f}, \mathrm{g} \in 3^{\mathrm{x}}$.

1.5 Definition: Let $R$ be a 3-ring. An element $a \in R$ is called an idempotent if $\mathrm{a}^{2}=\mathrm{a}$.

1.6 Lemma: An element $\mathrm{a} \in \mathrm{R}$ is an idempotent iff $1-\mathrm{a}$ is an idempotent.

Proof: Suppose a is an idempotent

Claim : (1-a) is an idempotent

$$
\begin{aligned}
&(1-\mathrm{a})^{2}=1+\mathrm{a}^{2}-2 \mathrm{a}=1+\mathrm{a}-2 \mathrm{a} \quad(\because \mathrm{a} \text { is idempotent }) \\
&=1-\mathrm{a} \\
& \therefore(1-\mathrm{a}) \text { is an idempotent }
\end{aligned}
$$

Conversely suppose that (1-a) is an idempotent

We have to show that $\mathrm{a}$ is an idempotent: 
$\because(1-\mathrm{a})$ is an idempotent

$1-(1-a)$ is an idempotent (By above)

$\Rightarrow \mathrm{a}$ is an idempotent element.

1.7 Lemma: For any element a in a 3-ring R, $\mathrm{a}^{2}$ is an idempotent.

Proof: Suppose $a \in R$

$\because \mathrm{R}$ is a 3 -ring, $\mathrm{a}^{3}=\mathrm{a}$

$\left(a^{2}\right)^{2}=a^{2} \cdot a^{2}=a^{3} \cdot a=a \cdot a=a^{2}$

$\therefore \mathrm{a}^{2}$ is an idempotent for every $\mathrm{a} \in \mathrm{R}$.

\section{Main Results}

2.1 Definition : A non empty subset $I$ of a 3-ring $R$ is said to be ideal

if (i) a, b $\in \square \mathrm{I} \Rightarrow \square \mathrm{a}+\mathrm{b} \in \square \mathrm{I}$, (ii) $\mathrm{a} \in \square \mathrm{I}, \mathrm{r} \in \mathrm{R} \Rightarrow \square \mathrm{a} \mathrm{r} \square \mathrm{ra} \in \square \mathrm{I}$.

Note: A non empty sub set $I$ of $R$ is said to be a right ideal (left ideal) of

$R$,if (i) $a, b \in I \Rightarrow a+b \in I$ (ii) $a \in I, r \in R \Rightarrow a ~ r \in I(r \quad a \in I)$

2.2 Note : Suppose $\mathrm{a} \in \mathrm{R}$ then there is minimal left ideal (right ideal) exists containing a which is called the principal right (left) ideal denoted by (a) $l((\mathrm{a}) r)$ is the set of all $\mathrm{ra}(\mathrm{ar}), \mathrm{r} \in \mathrm{R}$. i.e, $(\mathrm{a}) \mathrm{r}=\{\mathrm{ar} / \mathrm{r} \in \mathrm{R}\}$ and $(\mathrm{a}) l=\{\mathrm{ra} / \mathrm{r} \in \mathrm{R}\}$.

2.3 Note : The set of all right ideals form a partially ordered set with respect to set theoretical inclusion $\mathrm{I} \subseteq \mathrm{J}$. This set has a minimum element:

$0=(0)$ and a maximum one $: \mathrm{R}=(1) \mathrm{r}$.

2.4 Note (1) : For any set of ideals I1, I2 _... $\mathrm{G} \square$ a maximal ideal

I such that $\square \mathrm{I} \subseteq \square \mathrm{I} 1, \mathrm{I} 2, \ldots$. and $\mathrm{I} 1 \cap \square \mathrm{I} 2 \cap \square \ldots$ is the maximal ideal

contained in every ideal $\mathrm{I} 1, \mathrm{I} 2, \ldots$. and it is denoted by glb $\{\mathrm{I} 1, \mathrm{I} 2, \ldots$.$\} .$

(2)For any set of ideals I1, I2, ... $\square \square$ a minimal ideal I such that $\square$

$\mathrm{I} \subseteq \square \mathrm{I} 1, \mathrm{I} 2, \ldots$ and it is denoted by lub $\{\mathrm{I} 1, \mathrm{I} 2, \ldots$.$\} .$

2.5 Note : For the ideals I1, I2; glb $\{\mathrm{I} 1, \mathrm{I} 2\}$ is denoted by I1 $\wedge \square \mathrm{I} 2$. and lub $\{\mathrm{I} 1, \mathrm{I} 2\}$ is denoted by I1 $\vee \square \mathrm{I} 2$.

Thus the set of right ideals form a lattice with $\wedge, \vee \square$ Zero $(0)$, unit $R$.

2.6 Definition: The center of a 3 -ring $R$ is the set $C=\{a \in R / a x=x a, \forall x \in R\}$. C is a commutative ring with unit 1 .

2.7 Theorem: If $a, b$ are the idempotent elements in $C$,then $a b$ an idempotent and $a b \in C$ and also (a) $\wedge$ (b) $=$ (ab)

Proof:Let $R$ be a 3-ring .

Suppose $\mathrm{a}, \mathrm{b} \in \mathrm{R}$ and $\mathrm{a}, \mathrm{b}$ are idempotents.

$(a b)^{2}=a b \cdot a b=a^{2} \cdot b^{2}=a b$.

Therefore $\mathrm{ab}$ is an idempotent.

Let $\mathrm{x} \in \mathrm{R} \Rightarrow(\mathrm{ab}) \mathrm{x}=\mathrm{a}(\mathrm{bx})=\mathrm{a}(\mathrm{xb})=(\mathrm{ax}) \mathrm{b}=(\mathrm{xa}) \mathrm{b}=\mathrm{x}(\mathrm{ab})$

Therefore $(a b) x=x(a b)$

$\therefore \mathrm{ab} \in \mathrm{C} . \mathrm{ab}=\mathrm{ba} \in \mathrm{a}$ and also belongs to $\mathrm{b}$

$\therefore(\mathrm{ab}) * \subseteq(\mathrm{a}) *(\mathrm{~b}) * \Rightarrow(\mathrm{ab}) *=(\mathrm{a}) * \wedge(\mathrm{b}) *$

Let $\mathrm{x} \in(\mathrm{a}) * \wedge(\mathrm{b}) * \Rightarrow \mathrm{ax}=\mathrm{bx}=\mathrm{x}$

$\therefore \mathrm{abx}=\mathrm{x} \therefore \mathrm{x} \in(\mathrm{ab}) *$

$\therefore(a) * \wedge(b) * \subseteq(a b)$

$\therefore(a) * \wedge(b) *=(a b) *$

2.8 Theorem: If $a, b$ are idempotents in $C$, then $a+b-a b \in C$, idempotent and also (a)* $\vee(b) *=(a+b-a b) *$

Proof: $a+b-a b=1-(1-a)(1-b)$.

Since $a, b \in C \Rightarrow(1-a),(1-b) \in C$ and are idempotent.

$\Rightarrow 1-(1-a)(1-b) \in C$ and idempotent.

$\therefore \mathrm{a}+\mathrm{b}-\mathrm{a} \mathrm{b}$ is an idempotent and belongs to $\mathrm{C}$. 
(a) $* \vee(b) *=\left((a) * \vee(b) *{ }^{*}\right)^{*}=(1-(1-a)(1-b)) *=(a-b-a b) *$

$\therefore(a) * \vee(b) *=(a+b-a b) *$

2.9 Theorem: Center of a 3-ring $\mathrm{C}$ is a 3-ring

Proof: Let $\mathrm{a} \in \mathrm{C} \Rightarrow \mathrm{a} \in \mathrm{R}$

Since $R$ is a 3-ring and $a \in R$ then $a^{3}=a$ and $3 a=0$

We have

$3(\mathrm{a} x)=(3 \mathrm{a}) \mathrm{x}$

$=0 \mathrm{x} \quad($ since $\mathrm{R}$ is a 3 -ring $)$

$=0$.

Therefore 3(a x ) $=0, \forall \mathrm{a} \in \mathrm{R}, \mathrm{x} \in \mathrm{R}$.

Let $\mathrm{z} \in \mathrm{R}$

z. $a x=z$ a. $x$

$=\mathrm{x} . \mathrm{za}$

$=\mathrm{x}$ a z

$=\mathrm{x}$ a. $\mathrm{z}$

$=\mathrm{ax} \cdot \mathrm{z}$.

$\therefore \mathrm{a} \mathrm{x} \in \mathrm{C}$

Therefore $\mathrm{C}$ is 3-ring.

2.10 Definition: A set $\mathrm{R}$ is said to be a topological 3- ring if

1. $\mathrm{R}$ is a 3 - ring.

2. $\mathrm{R}$ is a topological space.

3. The operations,.,,$+-(-)^{*}$ are continuous.

2.11 Note : For any subsets $U, V \subseteq \square$, we define

$$
\begin{aligned}
& \mathrm{U}+\mathrm{V}=\{\mathrm{u}+\mathrm{v} / \mathrm{u} \in \square \mathrm{U}, \mathrm{v} \square \in \mathrm{V}\} \\
& \mathrm{U} \cdot \mathrm{V}=\{\mathrm{uv} / \mathrm{u} \square \in \mathrm{U}, \mathrm{v} \in \mathrm{V}\} . \\
& -\mathrm{U}=\{-\mathrm{u} / \mathrm{u} \square \in \mathrm{U}\} . \\
& \mathrm{U}^{*}=\left\{\mathrm{u}^{*} / \mathrm{u} \in \square \mathrm{U}\right\}
\end{aligned}
$$

2.12 Note : 1) $+: R \times R \rightarrow \square R$ is continuous means, for every neighbourhood $W$ of $a+b, a, b \in \square$ there exist neighbourhoods $\mathrm{U}$ of $\mathrm{a}, \mathrm{V}$ of $\mathrm{b}$ such that $\mathrm{U}+\mathrm{V} \subseteq \mathrm{W}$.

2) . : $\mathrm{R} \times \mathrm{R} \rightarrow \square \square \mathrm{R}$ is continuous, for every neighbourhood $\mathrm{W}$ of $\mathrm{ab}$, a, b $\square \in \mathrm{R}$, there exist neighbourhoods $\mathrm{U}$ of $\mathrm{a}, \mathrm{V}$ of $\mathrm{b}$ such that

$\mathrm{U} . \mathrm{V} \subseteq \square \mathrm{W}$.

3) $-: \mathrm{R} \rightarrow \square \square \mathrm{R}$ is continuous, if for every neighbourhood $\mathrm{W}$ of $-\mathrm{a}$, there exist a neighbourhood $\mathrm{U}$ of a such that $-\mathrm{U} \subseteq \square \mathrm{W}$.

4) $(-)^{*}: \mathrm{R} \rightarrow \square \square \mathrm{R}^{*}$ is continuous means, for every neighbourhood $\mathrm{W}$ of $\mathrm{a}^{*}$, there exist a neighbourhood $\mathrm{U}$ of a such that $\mathrm{U}^{*} \subseteq \mathrm{W}$.

2.13 Lemma : Suppose $R$ is a topological 3- ring. If c $\in \square R$, then

i) The map $x \rightarrow \square \square \mathrm{c}+x$, is homeomorphism.

ii) The maps $x \rightarrow \square \square \mathrm{c} x, x \rightarrow \square \square x \mathrm{c}$ are continuous.

Proof : The subspace $\{\mathrm{c}\} \times \mathrm{R}$ of $\mathrm{R} \times \mathrm{R}$ is clearly homeomorphic to $\mathrm{R}$ via $(\mathrm{c}, \mathrm{b}) \rightarrow \square \mathrm{b}$ and the restriction of + to $\{\mathrm{c}\} \times \mathrm{R}$ to $\mathrm{R}$ is continuous and clearly bijection. 


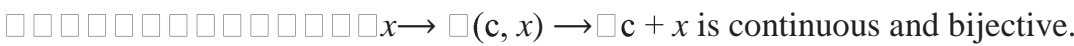

$\square \square \square \square \square \square \square \square \square \square \square \square \square x \rightarrow \square \mathrm{c}+x$ is continuous and bijective. And its inverse $x \rightarrow \square-\mathrm{c}+x$ is continuous and bijective. $\square \square x \rightarrow \square \mathrm{c}+x$ is homeomorphism.

The subspace $\{\mathrm{c}\} \times \mathrm{R}$ of $\mathrm{R} \times \mathrm{R}$ is clearly homeomorphic to $\mathrm{R}$

via (c, b) $\rightarrow \square$ b and the restriction of . to $\{\mathrm{c}\} \times \mathrm{R} \rightarrow \square \mathrm{R}$ is continuous. Similarly $x \rightarrow \square x \mathrm{c}$ is continuous.

2.14 Note : 1) $\mathrm{R}$ is a topological 3- ring. Since $-\mathrm{R} \rightarrow \square \mathrm{R}$ is clearly

homeomorphism. So $\mathrm{U}$ is open, $-\mathrm{U}$ is also open.

2) Since $x \rightarrow x+c$ is homeomorphic, then for any open $\mathrm{U} \subseteq \square \mathrm{R}, \mathrm{c} \in \square \mathrm{R}$, then $\mathrm{U}+\mathrm{c}=\{\mathrm{u}+\mathrm{c} / \mathrm{u} \in \square \square \mathrm{U}\}$ is open. If $\mathrm{U}, \mathrm{V}$ are open, then $\mathrm{U}+\mathrm{V}$ is open.

3) If $U$ is open neighbourhood of $c$ iff $U-c$ is an open neighbourhood of 0 . So,the topology of $R$ is completely determined by the open neighbourhoods of 0 .

2.15 Definition : Let $X$ be a topological space. If $x \in \square \square X$, then a fundamental system of neighbourhoods of $x$ is a non-empty set $\mathrm{M}$ of open neighbourhoods of $x$ with the property that, if $\mathrm{U}$ is open and $x \in \square \square \mathrm{U}$, then there is $\mathrm{V} \in \square \square \mathrm{M}$ with $\mathrm{V} \subseteq \square \mathrm{U}$.

2.16 Definition : Let $\mathrm{R}$ be a 3- ring. A non-empty set $\mathrm{N}$ of subsets of $\mathrm{R}$ is fundamental if it satisfies the following conditions.

(a) Every element of $\mathrm{N}$ contain 0 .

(b) If $\mathrm{U}, \mathrm{V} \in \square \mathrm{N}$, then there is $\mathrm{W} \in \square \mathrm{N}$ with $\mathrm{W} \subseteq \square \mathrm{U} \square \mathrm{V}$.

(0). For $\mathrm{U} \in \square \mathrm{N}$ and $\mathrm{c} \in \square \mathrm{U}$, there exist $\mathrm{V} \in \square \mathrm{N}$ such that $\mathrm{c}+\mathrm{V} \subseteq \square \mathrm{U}$.

(1). For each $\mathrm{U} \in \square \mathrm{N}$ there exist $\mathrm{V} \in \square \mathrm{N}$ such that $\mathrm{V}+\mathrm{V} \subseteq \square \mathrm{U}$.

(2). $U \in \square \mathrm{N}$ then $-\mathrm{U} \in \square \mathrm{N}$.

(3). If $\mathrm{U} \in \square \mathrm{N}$ there exist $\mathrm{V} \in \square \mathrm{N}$ such that $\mathrm{V}^{*} \subseteq \square \mathrm{U}$.

(4). For $\mathrm{c} \in \square \mathrm{R}$ and $\mathrm{U} \in \square \mathrm{N}$ there is $\mathrm{V} \in \square \mathrm{N}$ such that $\mathrm{c} \mathrm{V} \subseteq \square \mathrm{U}$ and $\mathrm{Vc} \subseteq \square \mathrm{U}$.

(5). For each $U \in \square \mathrm{N}$ there is $\mathrm{V} \in \square \mathrm{N}$ such that $\mathrm{V} \cdot \mathrm{V} \subseteq \square \mathrm{U}$.

2.17 Theorem : Suppose $\mathrm{R}$ is a topological 3- ring. Then the set $\mathrm{N}$ of open neighbourhoods of 0 satisfies.

(0). For $\mathrm{U} \in \square \mathrm{N}$ and $\mathrm{c} \in \square \mathrm{U}$, $\mathrm{G} \square \square \mathrm{V} \in \square \mathrm{N}$ such that $\mathrm{c}+\mathrm{V} \subseteq \square \mathrm{U}$.

(1). For each $\mathrm{U} \in \square \mathrm{N}$, there exist $\mathrm{V} \in \square \mathrm{N}$ such that $\mathrm{V}+\mathrm{V} \subseteq \square \mathrm{U}$.

(2). If $U \in \square N$, then $-U \in \square N$.

(3). If $\mathrm{U} \in \square \mathrm{N}$, then $\mathrm{B} \square \square \mathrm{V} \in \square \mathrm{N} \ni \square \mathrm{V}^{*} \subseteq \square \mathrm{U}$.

(4). For $\mathrm{c} \in \square \mathrm{R}$ and $\mathrm{U} \in \square \mathrm{N}$, there is $\mathrm{V} \in \square \mathrm{N}$ such that $\mathrm{c} \mathrm{V} \subseteq \square \mathrm{U}$ and $\mathrm{Vc} \subseteq \square \mathrm{U}$.

(5). For each $\mathrm{U} \in \square \mathrm{N}$ there is $\mathrm{V} \in \square \mathrm{N}$ such that $\mathrm{V} . \mathrm{V} \subseteq \square \mathrm{U}$.

Conversely, if $\mathrm{R}$ is a regular ring and $\mathrm{N}$ a non-empty set of subsets of $\mathrm{R}$

which satisfies N0, N1, N2, N3, N4 and N5 has the property that (a) every element of N contains 0 and (b) if $\mathrm{U}, \mathrm{V} \in \square \mathrm{N}$, then there is $\mathrm{W} \in \square \mathrm{N}$ such that $\mathrm{W} \subseteq \square \mathrm{U} \cap \square \mathrm{V}$, then there is a unique topology on $\mathrm{R}$ making $\mathrm{R}$ into a topological3-ring in such away that $\mathrm{N}$ is a fundamental system of neighbourhoods of 0 .

Proof :

N0 . Let $\mathrm{U} \in \square \mathrm{N}$ and $\mathrm{c} \in \square \mathrm{U}$, then $\mathrm{U}-\mathrm{c}$ is a neighbourhood of 0 .

$\square \square \square \square \square \square \square \Rightarrow \mathrm{G} \square$ a neighbourhood $\mathrm{V}$ of 0 such that $\mathrm{V} \subseteq \square \mathrm{U}-\mathrm{c} \Rightarrow \mathrm{V}+\mathrm{c} \subseteq \square \mathrm{U}$

N1. Let $\mathrm{U} \in \square \mathrm{N} \Rightarrow \square 0 \in \square \mathrm{U} \Rightarrow \square(0,0) \in \square+^{-1}(\mathrm{U})$

$\because \quad+$ is continuous, so $+^{-1}(\mathrm{U})$ is open and $(0,0) \in \square+^{-1}(\mathrm{U})$, $\mathrm{G} \square \square$ open sets, V1, V2 with $(0,0) \in \square \mathrm{V} 1$ $\times \mathrm{V} 2 \subseteq \square+{ }^{-1}(\mathrm{U})$.

Let $\mathrm{V}=\mathrm{V} 1 \cap \square \mathrm{V} 2 \Rightarrow \square(0,0) \in \square \mathrm{V} \times \mathrm{V} \subseteq \square+{ }^{-1}(\mathrm{U}) \Rightarrow \square \mathrm{V}+\mathrm{V} \subseteq \square \mathrm{U}$.

$\mathrm{N} 2$. Let $\mathrm{U} \in \square \mathrm{N} \Rightarrow \square \mathrm{U}$ neighbourhood of 0 .

$-: \mathrm{R} \rightarrow \square \mathrm{R}$ is homeomorphic and $\mathrm{U}$ is open $\Rightarrow \square-\mathrm{U}$ is open.

$\because 0 \in \square \mathrm{U} \Rightarrow \square 0 \in \square-\mathrm{U} . \therefore \square-\mathrm{U} \in \square \mathrm{N}$.

N3. $\quad \because *: \mathrm{R} \rightarrow \square \mathrm{R}$ is continuous and $\mathrm{U}$ is a neighbourhood of 0 , then

$*^{-1}(\mathrm{U})$ is open and $0 \in \square^{*-1}(\mathrm{U}) . \Rightarrow \square \mathrm{G} \square$ a neighbourhood $\mathrm{V}$ of 0 such that $\mathrm{V} \subseteq \square{ }^{*-1}(\mathrm{U}) \Longrightarrow \square \mathrm{V}^{*} \subseteq \square \mathrm{U}$. 
N4. Let $\mathrm{U} \in \square \mathrm{N}$ and $\mathrm{c} \in \square \mathrm{R} \Rightarrow \square \mathrm{U}$ is neighbourhood of $0 . x \subseteq \square \mathrm{c} x$ is continuous and $\mathrm{U}$ is neighbourhood of 0 , then $\mathrm{G} \square$ a neighbourhood $\mathrm{V}$

of 0 such that $\mathrm{cV} \subseteq \square \mathrm{U}$ (By taking $x=0$ ). Similarly $\mathrm{Vc} \subseteq \square \mathrm{U}$.

N5. Let $\mathrm{U} \in \square \mathrm{N} \Rightarrow \square \mathrm{U}$ is a neighbourhood of 0 .

$\because$ multiplication . is continuous,.$\square^{-1}(\mathrm{U})$ is open and contains $(0,0)$.

$\square \Rightarrow \square \exists \square$ neighbour hoods $\mathrm{V} 1, \mathrm{~V} 2$ of 0 such that $(0,0) \in \square \mathrm{V} 1 \times \mathrm{V} 2 \subseteq \square .^{-1}(\mathrm{U})$.

Let $\mathrm{V}=\mathrm{V} 1 \cap \square \mathrm{V} 2 \Rightarrow \square(0,0) \in \square \mathrm{V} \times \mathrm{V} \subseteq \square \square^{-1}(\mathrm{U}) \Rightarrow \square \mathrm{V} . \mathrm{V} \subseteq \square \mathrm{U}$.

Conversely suppose $\mathrm{R}$ is a regular ring and $\mathrm{N}$ be a non-empty set of

subsets of $\mathrm{R}$ with the given properties. We define a subset $\mathrm{U}$ of $\mathrm{R}$ to be open if for every $x \in \square \mathrm{U}, \mathrm{B} \square \mathrm{W} \in \square \mathrm{N}$ $\square x+\mathrm{W} \subseteq \square \mathrm{U}$.

Clearly this is a topology.

For : Clearly $\emptyset, \mathrm{R}$ are open.

Suppose $\{\mathrm{U} \alpha \square / \alpha \square \in \square \Delta\}$ is a family of open sets.

Let $\mathrm{U}=\mathrm{UU}$

$\square \square \square \square \square \square \square \square \square \square \square \square \square \alpha \in \Delta$

Let $x \in \square \mathrm{U} \Rightarrow \square x \in \mathrm{UU}$

$\alpha \in \Delta$

$\Rightarrow \square x \in \square \mathrm{U} \alpha \square$ for some $\alpha \square \in \square \Delta \square \Rightarrow \square \mathrm{G} \square \square \square \mathrm{V} \in \square \mathrm{N} \ni \square \mathrm{V}+x \subseteq \square \mathrm{U} \alpha$

$\Rightarrow \square \mathrm{V}+x \subseteq \square \mathrm{U} \square \mathrm{U}$



$\Rightarrow \square \mathrm{V}+x \subseteq \square \mathrm{U}$.

$\therefore \square \square \mathrm{U}$ is an open set.

Let $\mathrm{U} 1, \mathrm{U} 2$ be two open sets. Let $\mathrm{U}=\mathrm{U} 1 \cap \square \mathrm{U} 2$.

Let $x \in \square \mathrm{U} \square \Rightarrow x \in \square \mathrm{U} 1$ and $x \in \square \mathrm{U} 2 \Rightarrow \square \mathrm{G} \square \mathrm{V} 1, \mathrm{~V} 2 \in \square \mathrm{N} \ni \square \mathrm{V} 1+x \subseteq \square \mathrm{U} 1, \mathrm{~V} 2+x \subseteq \square \mathrm{U} 2$.Then $\mathrm{G} \square \square \mathrm{V} \in$ $\square \mathrm{N} \ni \square \mathrm{V} \subseteq \square \mathrm{V} 1 \cap \square \mathrm{V} 2$. Then $\mathrm{V}+x \subseteq \square \mathrm{U} 1, \mathrm{~V}+x \subseteq \square \mathrm{U} 2$.

$\therefore \square \mathrm{V}+x \subseteq \square \mathrm{U} 1 \cap \square \mathrm{U} 2 . \therefore \square \square \mathrm{U} 1 \cap \square \mathrm{U} 2$ is open.

Let $\mathrm{U} \in \square \mathrm{N}$ and $x \in \square \mathrm{R}$. Then $\mathrm{G} \square \square \mathrm{V} \in \square \mathrm{N} \exists \square \mathrm{V}+x \subseteq \square \mathrm{U}$ (By N0)

$\therefore \square \square$ The sets in $\mathrm{N}$ are also open sets containing 0 .

Claim : If $\mathrm{U}$ is open, then for $\mathrm{c} \in \square \mathrm{R}, \mathrm{c}+\mathrm{U}$ is open.

Let $\mathrm{b} \in \square \mathrm{c}+\mathrm{U} \Rightarrow \square \mathrm{b}-\mathrm{c} \in \square \mathrm{U}$.

$\therefore \square \square \mathrm{G} \square \square \mathrm{V} \in \square \mathrm{N} \ni \square \mathrm{b}-\mathrm{c}+\mathrm{V} \subseteq \square \mathrm{U}(\mathrm{By}(\mathrm{N} 0) \Rightarrow \square \mathrm{b}+\mathrm{V} \subseteq \square \mathrm{c}+\mathrm{U}$.

$\therefore \square \mathrm{c}+\mathrm{U}$ is open set.

Claim : $+: \mathrm{R} \times \mathrm{R} \rightarrow \square \mathrm{R}$ is continuous.

Let $\mathrm{U}$ be an open set. Let (c, d) $\in \square+^{-1}(\mathrm{U}) \Rightarrow \square \mathrm{c}+\mathrm{d} \in \square \mathrm{U}$.

$\therefore \square \square \mathrm{G} \square \square \mathrm{W} \in \square \mathrm{N} \ni \square \mathrm{c}+\mathrm{d}+\mathrm{W} \subseteq \square \mathrm{U} . \because \mathrm{W} \in \square \mathrm{N}$, by N1, $\square \square \square \mathrm{Q} \in \square \mathrm{N} \exists \square \mathrm{Q}+\mathrm{Q} \subseteq \square \mathrm{W}$.

$\therefore \square \square \mathrm{c}+\mathrm{d}+\mathrm{Q}+\mathrm{Q} \subseteq \square \mathrm{c}+\mathrm{d}+\mathrm{W} \subseteq \square \mathrm{U} \Rightarrow \square(\mathrm{c}, \mathrm{d}) \in \square(\mathrm{c}+\mathrm{Q}) \times(\mathrm{d}+\mathrm{Q}) \subseteq \square+^{-1}(\mathrm{U})$.

$\therefore \square+^{-1}(\mathrm{U})$ is open. $\therefore \square \square+$ is continuous.

Claim : $-: \mathrm{R} \rightarrow \square \mathrm{R}$ is continuous.

Let $\mathrm{U}$ be an open set. Let $\mathrm{b} \in \square-\mathrm{U} \Longrightarrow \square-\mathrm{b} \in \square \mathrm{U}$.

From N0, $\mathrm{A} \square \square \mathrm{V} \in \square \mathrm{N} \ni \square-\mathrm{b}+\mathrm{V} \subseteq \square \mathrm{U} \Rightarrow \square \mathrm{b}-\mathrm{V} \subseteq \square-\mathrm{U}$.

$\therefore \square \square-\mathrm{U}$ is open. ( $\because \mathrm{V} \in \square \mathrm{N} \Rightarrow \square-\mathrm{V} \in \square \mathrm{N}$ by N2). $\therefore \square \square-$ is continuous

.Claim : The map $\theta \square: \mathrm{R} \rightarrow \square \mathrm{R}$ by $x \rightarrow \mathrm{c} x$ is continuous.

Let $\mathrm{U}$ be an open set. Let $x \in \theta^{-1} \square(\mathrm{U}) \Rightarrow \theta \square(x) \in \square \mathrm{U} \Rightarrow \square \mathrm{c} x \square \in \mathrm{U}$

$\square \Rightarrow \mathrm{G} \square \square \mathrm{W} \in \square \mathrm{N} \ni \square \mathrm{c} x+\mathrm{W} \subseteq \square \mathrm{U}(\mathrm{By} N$ ). Q W $\in \square \mathrm{N}, \mathrm{B} \square \square \mathrm{V} \in \square \mathrm{N} \exists \square \mathrm{cV} \subseteq \square \mathrm{W}$.

Then $x+\mathrm{V} \subseteq \square \theta^{-1}(\mathrm{U}) . \therefore \square \square \theta^{-1}(\mathrm{U})$ is open

$\therefore \square \square \theta \square$ i.e., $x \rightarrow \square \mathrm{c} x$ is continuous. Similarly $x \rightarrow \square x \mathrm{c}$ is continuous.

Claim : $\mathrm{m}: \mathrm{R} \times \mathrm{R} \rightarrow \square \mathrm{R}$ is continuous, where $\mathrm{m}(\mathrm{a}, \mathrm{b})=\mathrm{a} \cdot \mathrm{b}$

Let $\mathrm{U}$ be an open set and (c, d) $\in \square \mathrm{m}^{-1}$ (U).

The maps $\theta \square: \mathrm{R} \rightarrow \square \mathrm{R}$ and $\Psi \square: \mathrm{R} \rightarrow \square \mathrm{R}$ where $\theta(x)=\mathrm{c} x, \Psi(x)=x \mathrm{c}$ are

continuous.

$\because(\mathrm{c}, \mathrm{d}) \in \square \mathrm{m}^{-1}(\mathrm{U}) \Rightarrow \square \mathrm{m}(\mathrm{c}, \mathrm{d}) \in \square \mathrm{U} \Rightarrow \square \mathrm{c} \mathrm{d} \in \square \mathrm{U}$

$\Rightarrow \square \mathrm{B} \square \square \mathrm{W} \in \square \mathrm{N} \ni \square \mathrm{c} \mathrm{d}+\mathrm{W} \subseteq \square \mathrm{U}$ (By N0).

$\because \mathrm{W} \in \square \mathrm{N}, \mathrm{B} \square \square \mathrm{Q} \in \square \mathrm{N} \ni \square \mathrm{Q}+\mathrm{Q} \subseteq \square \mathrm{W}($ By N1)

$\because \mathrm{Q} \in \square \mathrm{N}, \mathrm{G} \square \square \mathrm{V} \in \square \mathrm{N} \ni \square \mathrm{V} . \mathrm{V} \subseteq \square \mathrm{Q}$ (By N5).

$\because \mathrm{Q} \in \square \mathrm{N}, \mathrm{B} \square \square \mathrm{P} \in \square \mathrm{N} \exists \square \mathrm{P}+\mathrm{P} \subseteq \square \mathrm{Q}(\mathrm{By}$ N1). 
Let $\mathrm{Pd}=\Psi^{-1}(\mathrm{P}) \cap \square \mathrm{Q} \cap \square \mathrm{V}, \mathrm{Pc}=\theta^{-1}(\mathrm{P}) \cap \square \mathrm{Q} \cap \square \mathrm{V}$.

Then (c, d) $\in \square(\mathrm{c}+\mathrm{Pd}) \times(\mathrm{d}+\mathrm{Pc}) \subseteq \square \mathrm{m}-1(\mathrm{U}) . \therefore \square \square \mathrm{m}$ is continuous.

Claim : * $: \mathrm{R} \rightarrow \square \mathrm{R}$ is continuous. Let $\mathrm{U}$ be an open set.

Let $x \in \square^{*-1}(\mathrm{U}) \Longrightarrow \square x^{*} \in \square \mathrm{U} \Rightarrow \square \mathrm{U}-x^{*}$ is a neighbourhood of 0

$\therefore \square \square \mathrm{B} \square \square \mathrm{V} \in \square \mathrm{N} \ni \square \mathrm{V}^{*} \subseteq \square \mathrm{U}-x^{*} \Rightarrow \square x^{*}+\mathrm{V}^{*} \subseteq \square \mathrm{U}$.

Suppose $\square \square$ is another topology on $\mathrm{R}$ for which $\mathrm{N}$ is a fundamental system

of neighbourhoods of 0 in this topology. Then the topology $\square \square$ and the topology

defined above have same open base.

$\therefore \square$ The topology $\square \square$ must agree with the topology we have defined above.

$\therefore \square \square$ The topology is unique.

$\therefore \square \square \mathrm{N}$ generates a unique topology on $\mathrm{R}$ for which $\mathrm{N}$ is a fundamental system of neighbourhoods of 0 .

2.18 Note : If $\mathrm{R}$ is a 3- ring then $\mathrm{R}$ has no non-zero nilpotent elements, every prime ideal is maximal and Jacobson radical of $\mathrm{R}$ is $\{0\}$.

2.19 Theorem : Suppose $\mathrm{R}$ is a topological 3- ring. S, T are subsets of R

.Then a) ST, $\mathrm{S}+\mathrm{T}$ are compact whenever $\mathrm{S}, \mathrm{T}$ are compact.

b) $-\mathrm{S}, \mathrm{S*}$ are compact whenever $\mathrm{S}$ is compact.

c) ST, S + T are connected sets whenever S, T are connected sets.

d) $-\mathrm{S}, \mathrm{S}^{*}$ are connected whenever $\mathrm{S}$ is connected.

Proof :

a) Since continuous image of a compact set is compact.

,.$+: \mathrm{R} \times \mathrm{R} \rightarrow \square \mathrm{R}$ are continuous, $\mathrm{S}, \mathrm{T}$ are compact sets, then

$(\mathrm{S} \times \mathrm{T})=\mathrm{ST}$,

$+(\mathrm{S} \times \mathrm{T})=\mathrm{S}+\mathrm{T}$ are compact.

b) $\because \quad-: \mathrm{R} \rightarrow \square \mathrm{R}$ and $*: \mathrm{R} \rightarrow \square \mathrm{R}$ are continuous and $\mathrm{S}$ in compact, then $-\mathrm{S}, \mathrm{S} *$ are compact.

c) $\because \quad$ continuous image of a connected set in connected,.$: \mathrm{R} \times \mathrm{R} \rightarrow \square \mathrm{R}$ and $+: \mathrm{R} \times \mathrm{R} \rightarrow \square \mathrm{R}$ are continuous, $.(\mathrm{S} \times \mathrm{T})=\mathrm{ST},+(\mathrm{S} \times \mathrm{T})=\mathrm{S}+\mathrm{T}$ are connected sets.

d) $\because \quad-: \mathrm{R} \rightarrow \square \mathrm{R}, *: \mathrm{R} \rightarrow \square \mathrm{R}$ are continuous and $\mathrm{S}$ is connected, so $-\mathrm{S}, \mathrm{S} *$ are connected.

2.20 Theorem : The union of all connected subsets contain 0 is a topological Sub 3-ring.

Proof : Suppose $\{$ Si $/ i \in \square \mathrm{I}\}$ is a class of all connected sets containing 0 .

Let $\mathrm{S}=\cup \mathrm{S} i$

$i \in \square \mathrm{I}$.

$\because 0 \in \square \mathrm{S} \Rightarrow \square 0 \in \square \mathrm{Si}$ for some $i \in \square \mathrm{I} \Rightarrow \square 1-0 \square \in-\mathrm{S} i \Rightarrow \square 1 \in \square-\mathrm{S} i$

$\because \mathrm{S} i$ is connected, $-\mathrm{S} i$ is also connected.

$\square \therefore \square \square \square 1 \in \square \mathrm{S}$. Let $\mathrm{a} \in \square \mathrm{S} \Rightarrow \square \mathrm{a} \in \square \mathrm{K} i$ for some $i \Rightarrow \square-\mathrm{a} \in \square-\mathrm{K} i \Longrightarrow \square-\mathrm{a} \in \square \mathrm{S}$.

$\therefore \square \square \square \square \mathrm{a} \in \square \mathrm{S} \Rightarrow \square-\mathrm{a} \in \square \mathrm{S}$

Suppose a, $\mathrm{b} \in \square \mathrm{S} \Rightarrow \square \mathrm{a} \in \square \mathrm{S} i, \mathrm{~b} \in \square \mathrm{S} j \Rightarrow \square \mathrm{a}+\mathrm{b} \in \square \mathrm{Si}+\mathrm{S} j$

$\therefore \square \mathrm{a}+\mathrm{b} \in \square \mathrm{S}(\because \mathrm{S} i+\mathrm{S} j$ is connected $)$

$\therefore \square \mathrm{S}$ is a topological sub 3- ring of R.

2.21 Theorem : Suppose R is a topological 3- ring and I is ideal of R. Then

$\bar{I}$ is also an ideal of $R$.

Proof : Suppose I is an ideal of R. $\overline{\mathrm{I}}=\{\mathrm{a} \in \square \mathrm{R} /$ every neighbourhood of a intersects I $\}$

Claim : $\overline{\mathrm{I}}$ is an ideal. Let $\mathrm{a}, \mathrm{b} \in \square \overline{\mathrm{I}}$

$\Rightarrow \square$ Every neighbourhood of a, every neighbourhood of $\mathrm{b}$ intersects I.

Suppose $\mathrm{W}$ is a neighbourhood of $\mathrm{a}+\mathrm{b}$.

$\Longrightarrow \square \mathrm{A} \square$ neighbour hood $\mathrm{U}$ of a, neighbourhood $\mathrm{V}$ of $\mathrm{b}$ such that $\mathrm{U}+\mathrm{V} \subseteq \square \mathrm{W}$.

$\because \mathrm{U}$ intersects I, $\mathrm{V}$ intersects I so $\mathrm{U}+\mathrm{V}$ intersects I, then $\mathrm{W}$ intersects I.

$\therefore \square \mathrm{a}+\mathrm{b} \in \square \mathrm{I}$. Let $\mathrm{a} \in \square \mathrm{I}, \mathrm{b} \in \mathrm{R}$.

Claim : a $b \in \square \overline{\mathrm{I}} . \because \mathrm{a} \in \square \overline{\mathrm{I}} \Rightarrow \square$ Every neighbourhood of a intersects I.

Let $\mathrm{W}$ be a neighbourhood of ab. then $\mathrm{B} \square$ neighbourhood $\mathrm{U}$ of a, neighbourhood $\mathrm{V}$ of $\mathrm{b} \ni \square \mathrm{UV} \subseteq \square \mathrm{W}$.

$\because \mathrm{U} \cap \square \mathrm{I} \square \neq \square \mathrm{A} \square \mathrm{a} \in \square \mathrm{U} \exists \square \mathrm{a} \in \square \mathrm{I}$. Let a $\mathrm{b} \in \square \mathrm{UV} \Rightarrow \square \mathrm{a} b \in \mathrm{I}(\because \mathrm{a} \in \square \mathrm{I})$

$\therefore \square \mathrm{UV} \cap \square \mathrm{I} \neq \square . \therefore \square \mathrm{UV}$ intersects I.

$\because \mathrm{UV} \subseteq \square \mathrm{W}$, so W intersects I. $\therefore \square \mathrm{a} b \in \square \overline{\mathrm{I}}$

Similarly ba $\in \square \overline{\mathrm{I}} . \therefore \square \overline{\mathrm{I}}$ is an ideal of R. 
2.22 Theorem : Every maximal ideal $\mathrm{M}$ of a topological 3- ring $\mathrm{R}$ is closed.

Proof : Clearly $\mathrm{M} \subseteq \square \overline{\mathrm{M}} \square . \because \overline{\mathrm{M}} \square$ is ideal, so $\mathrm{M}=\overline{\mathrm{M}} \square \quad \therefore \square \mathrm{M}$ is closed.

2.23 Theorem : If a topological 3- ring is T2 space then it is a Hausdorff

space.

Proof : Suppose R is a T2 space and a, $\mathrm{b} \in \square \mathrm{R}$ and $\mathrm{a} \neq \square \mathrm{b}$.

$\because \mathrm{R}$ is a T2 space $\mathrm{B} \square$ neighbourhood $\mathrm{U}$ of a and neighbourhood $\mathrm{V}$ of

$\mathrm{b} \ni \square \mathrm{a} \notin \notin \square \mathrm{V}, \mathrm{b} \notin \notin \square \mathrm{U}$. Suppose $\mathrm{U} \cap \square \mathrm{V} \neq \square$

Let $\mathrm{W}=\mathrm{U} \cap \square \mathrm{V}$. Let $\mathrm{c} \in \square \mathrm{W} \Rightarrow \square \mathrm{W}-\mathrm{c}$ is neighbourhood of 0 .

Let $\mathrm{K}=\mathrm{W}-\mathrm{c} \Rightarrow \square \mathrm{K}$ is neighbourhood of 0 .

$\Rightarrow \square \mathrm{K}+\mathrm{a}$ and $\mathrm{K}+\mathrm{b}$ are neighbourhoods of $\mathrm{a}$ and $\mathrm{b}$ respectively and

$(\mathrm{K}+\mathrm{a}) \cap \cap \square(\mathrm{K}+\mathrm{b})=\square$.

$\therefore \square \mathrm{R}$ is Hausdorff space.

2.24 Theorem : Every topological 3-ring is a homogeneous algebra.

ie., for every $\mathrm{p}, \mathrm{q}(\mathrm{p} \neq \mathrm{q})$ there is a continuous map $\mathrm{f}: \mathrm{R} \rightarrow \square \mathrm{R}$ such that $\mathrm{f}(\mathrm{p})=\mathrm{q}$.

Proof : $\mathrm{R}$ is a topological 3- ring. Let $\mathrm{c}=\mathrm{q}-\mathrm{p}$, then the function $\mathrm{f}: \mathrm{R} \rightarrow \square \mathrm{R}$

by $\mathrm{f}(x)=\mathrm{c}+x$ is continuous and $\mathrm{f}(\mathrm{p})=\mathrm{c}+\mathrm{p}=\mathrm{q}-\mathrm{p}+\mathrm{p}=\mathrm{q}$.

2.25 Theorem : Suppose $\mathrm{R}$ is a topological 3-ring and $\mathrm{X}=\operatorname{spec} \mathrm{R} . \mathrm{R} *$ is a

complete Boolean algebra. Suppose $\mathrm{M}$ is a subset of $\mathrm{Spec} \mathrm{R}=\mathrm{X}$.

Denote $\mathrm{QM}$, the set of elements e $\in \square \mathrm{R}^{*}$ for which $\mathrm{M} \subseteq \square \mathrm{X}$ e. Then $\mathrm{X} \wedge \square \mathrm{QM} \subseteq \square \overline{\mathrm{M}}$. In particular if $\mathrm{M}$ is nowhere dense in Spec R, then $\wedge \square \mathrm{QM}=0$.

Proof : Let $x \in \square \mathrm{X} \wedge \square \mathrm{QM}$.

Suppose $x \notin \notin \square \overline{\mathrm{M}} . \Rightarrow \square \mathrm{G} \square$ a neighbourhood $\mathrm{X}$ e of the point $\ni \square \mathrm{X}$ e $\cap \square \mathrm{M}=\varnothing$.

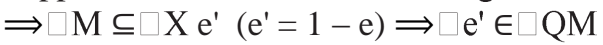

$\therefore \square \mathrm{e} \wedge \square \square(\wedge \square \mathrm{QM}) \subseteq \square \mathrm{e} \wedge \square \mathrm{e} 1=0$

i.e., e $\wedge \square(\wedge \square \mathrm{QM})=0 \Rightarrow \square \mathrm{X}$ e $\wedge \square(\wedge \square \mathrm{QM})=\varnothing \square \Rightarrow \square \mathrm{X}$ e $\cap \square \mathrm{X} \wedge \square \mathrm{QM}=\varnothing$

It is a contradiction ( $\mathrm{Q} x \in \square \mathrm{X} \wedge \square \mathrm{QM}$ and $x \in \square \mathrm{X}$ ) $). \therefore \square x \in \square \overline{\mathrm{M}}$.

$\square \therefore \mathrm{X} \wedge \square \square \mathrm{QM} \subseteq \square \overline{\mathrm{M}}$. . Suppose $\mathrm{M}$ is nowhere dense.

$\Rightarrow \overline{\mathrm{M}} \square$ contains no non-empty open subset.

But $\mathrm{X} \wedge \square \mathrm{QM} \subseteq \overline{\mathrm{M}} \square \Rightarrow \square \mathrm{X} \wedge \square \mathrm{QM}=\varnothing \quad \square \Rightarrow \square \wedge \square \mathrm{QM}=0$.

\section{Reference}

[1]. A.L.Foster,The theory of Boolean like rings,Trans.Amer.Math.Soc.,59 (1946),pp:166-187.

[2]. Jacobson. N, Basic algebra-2, Hindustan Publishing Corporation, 1994.

[3]. Jacobson. N; Totally disconnected locally compact rings, Amer. J. Math. 58 (1936), 433-449.

[4]. Koteswara Rao, P: A*-Algebra an If-Then-Else structures (Doctoral Thesis) 1994, Nagarjuna University, A.P., India.

[5]. M.H. McCoy, and Montgomery, A representation of generalized Boolean

[6]. rings. Duke Math. J. 3 (1937), 455-459. 6.M,H.Stone,The theory of representation of Boolean algebras, Trans.Amer.Math.Soc.40 (1936),pp:37-111.

[7]. Pontryagin. L.S., Topological groups, English transl., 2nd Russian ed; Gordan and Breach, Newyork, 1966.

[8]. Pontryagin. L.S., Uberstetige algebraische Korper, Ann. of Math. 33 (1932), 163-174.

[9]. Skornjakov. L.A., Einfachelokal bikompakte Ringe, Math. Z. 87 (1965), 241-75.

[10]. Small. L., Reviews in Ring theory, 1940-1970, Amer, Math. Soc. Providence, RI, 1981.

[11]. Van Dantzig. D., Studien Over Topologische algebra, Paris. H.J., Amsterdam, 1931 (Dutch).

[12]. Warner. S; Topological fields, North. Holland Mathematical studies, Vol. 157, North-Holland, Amsterdam / New York (1989).

[13]. Warner. S, Topological Rings, North-Holland Mathematics studies, Vol. 178, Elsevier, Amsterdam / London / New York /Tokyo 1993. 